\title{
Response of Anna Apple Trees to Foliar Application of Moringa Oil
}

\author{
Mahmoud R. Gad El-Kareem ${ }^{1}$
}

\begin{abstract}
Anna apple trees received Moringa oil at 0.025 to $0.2 \%$ once, twice, thrice or four times during 2018 and 2019 seasons. The merit was examining the effect of different concentrations and frequencies of Moringa oil on the growth and fruiting of anna apple.

Using Moringa oil at various concentrations and frequencies announced the promotion on growth, tree nutritional status, yield and fruit quality compared to the check treatment. The promotion was materially associated with increasing concentration and frequencies of Moringa oil. Increasing concentrations from 0.1 to $0.2 \%$ and frequencies from three to four times had a negligible promotion on the investigated parameters.
\end{abstract}

The best results with regard to yield and fruit quality of Anna apple trees were obtained due to treating the trees three times with Moringa at $0.1 \%$.

Keywords: Anna apple, Moringa oil.

\section{INTRODUCTION}

Newly, public health and environmental safety encourage using plant extracts to enhance fruiting of fruit crops instead of chemicals. Previous studies showed that the crucial function of Moringa oil on improving fruit crops could be due to its higher content from vitamins $\mathrm{E}, \mathrm{A}, \mathrm{B}_{1} \& \mathrm{~B}_{2} \& \mathrm{C}$ and $\mathrm{K}$, Minerals, in particular $\mathrm{Ca}, \mathrm{K}, \mathrm{N}, \mathrm{P}$ and $\mathrm{Mn}$ and amino acids, in particular phenylalanine, lysine, leucine, threonine isoleucine, arginine, cysteine, methionene and treptophane (Srimal, 1997; Pons, 2003 and Parakash and Majeed, 203).

Previous studies demonstrated the beneficial effects of using plant extracts on fruiting of horticultural crops (Borek, 2001; Amagase, 2006; Chowdhury et al., 2007; Amault and Auger, 2006; El- Masry and Abd ElRahman, 2012; Mohamed and Mohamed, 2013; Gad ElKareem and Abd El- Rahman, 2013; Uwakiem, 2014; Sheren and El-Amary 2015; Nasira et al., 2016; Thanaa et al., 2017 and Fatma et al., 2020).

The objective of this study was investigating the effect of various concentrations and frequencies of Moringa oil on fruiting of Anna apple trees.

\section{MATERIALS AND METHODS}

This study was carried out during 2018 and 2019 seasons on Anna apple trees grow, in an orchard located at West Samalout, Samalout district, Minia
Governorate. Fifty - one Anna apple trees onto MM106 rootstock were selected to be as uniform as possible and devoted to achieving this study. Trees were ten -old at the starting of this investigation. The planting distance is $3.5 \times 3.5$ meters apart and the texture of the soil is sandy. Cross-pollination was secured using Dorset Golden and Ein Shemr as pollinizers distributed in the whole orchard. Horticultural practices were carried out as usual. Drip irrigation system was used:

This experiment included the following seventeen treatments:

1- Control.

2- Spraying Moringa oil at $0.025 \%$ once at growth start (mid-March).

3- Spraying Moringa oil at $0.025 \%$ twice at growth start and at three weeks later $\left(2^{\text {nd }}\right.$ week of April).

4- Spraying Moringa oil at $0.025 \%$ thrice at growth start and twice at three-week intervals $\left(2^{\text {nd }}\right.$ week of April and $1^{\text {st }}$ week of May).

5- Spraying Moringa oil at $0.025 \%$ four times at growth start and thrice at three weeks intervals $\left(2^{\text {nd }}\right.$ week of April, $1^{\text {st }}$ week of May and last week of May).

6- $\quad$ Spraying Moringa oil at $0.05 \%$ once as previously mentioned

7- Spraying Moringa oil at $0.05 \%$ twice previously mentioned.

8- $\quad$ Spraying Moringa oil at $0.05 \%$ thrice previously mentioned.

9- Spraying Moringa oil at $0.05 \%$ four times previously mentioned.

10- Spraying Moringa oil at $0.1 \%$ once previously mentioned.

11- Spraying Moringa oil at $0.1 \%$ twice previously mentioned.

12- Spraying Moringa oil at $0.1 \%$ thrice previously mentioned.

13- Spraying Moringa oil at $0.1 \%$ four times previously mentioned.

14- Spraying Moringa oil at $0.2 \%$ once previously mentioned.

15- Spraying Moringa oil at $0.2 \%$ twice previously mentioned.

16- Spraying Moringa oil at $0.2 \%$ thrice previously mentioned.

17- Spraying Moringa oil at $0.2 \%$ four times previously mentioned.

${ }^{1}$ Hort. Dept., Fac. of Agric., Sohag Univ., Egypt

E mail: Mahmoud_rg@ @hotmail.com

Received October 05, 2021, Accepted November 10, 2021 
Table 1. Chemical composition of Moringa oil (Moringa oleifera)

\begin{tabular}{lc}
\hline Constituent & Values \\
\hline a) vitamins (mg / 100 g F.W.) & \\
\hline Beta carotene & 1500 \\
E & 500 \\
A & 900 \\
B1 & 902 \\
B2 & 7.1 \\
C & 180.0 \\
K & 250 \\
b) Minerals (mg / 100 g F.W.) & \\
\hline Ca & 900 \\
K & 500 \\
N & 900 \\
P & 130 \\
Mg & 199.0 \\
c) Amino acids ( mg/ 100 g F.W.) & \\
\hline Phenylalanine & $\mathbf{8 3 . 9}$ \\
Lysine & $\mathbf{7 5 . 0}$ \\
Leucine & $\mathbf{8 9 . 9}$ \\
Threonine & 65.0 \\
Arginine & 66.0 \\
Cysteine & 28.0 \\
Metheonine & $\mathbf{3 6 . 0}$ \\
\hline Treptophane & 33.0 \\
\hline
\end{tabular}

Each treatment was replicated three times, one Anna apple tree per each. Randomized complete block design was followed. Triton B was added to all Moringa oil concentrations at $5 \mathrm{ml} / 20 \mathrm{~L}$ water as a wetting agent. Spraying was done till runoff. Chemical analysis of Moringa oil is presented in table (1): (A.O.A.C., 2000). In the first week of June, took twenty leaves picked from the middle of current shoot from each tree for measuring the leaf area (Ahmed and Morsy, 1999) and percentages of $\mathrm{N}, \mathrm{P}, \mathrm{K}$ and $\mathrm{Mg}$ on dry weight basis (Wilde et al., 1985). At harvest time (last week of July) during both seasons, yield/ tree $(\mathrm{kg}$.) was recorded. Took ten fruits from each tree for measuring average fruit weight (g.), T.S.S. \%, reducing and total sugars $\%$ (A.O.A.C., 2000); total acidity \% (as g malic acid / 100 $\mathrm{ml}$ pulp), (A.O.A.C. , 2000) and total anthocyanins in the peel ( $\mathrm{mg} / 100 \mathrm{~g} \mathrm{F.W.)} \mathrm{(Fulcki} \mathrm{and} \mathrm{Francis,} \mathrm{1965).}$

Statistical analysis was done (Mead et al., 1993). Treatment means were compared using new L.S.D. test at $5 \%$.

\section{RESULTS}

\section{Leaf area:}

It is clear from the data in Table (2) that spraying Moringa oil at 0.025 to $0.2 \%$ once, twice, thrice or four times significantly enhanced the leaf area of Anna apple trees relative to the control treatment. The leaf area's promotion was associated with increasing concentrations from 0.025 to $0.2 \%$ and frequencies from one to four times. Increasing concentrations from 0.1 to $0.2 \%$ and frequencies from thrice to four times had no significant promotion on the leaf area. The maximum values of the leaf area were recorded on the trees that were sprayed four times with Moringa oil at $0.2 \%$. Untreated trees produced the minimum values. These results were found during $2018 \& 2019$ seasons.

\section{Percentages of $\mathrm{N}, \mathrm{P}, \mathrm{K}$ and $\mathrm{Mg}$ in the leaves:}

Data in Tables ( $2 \&$ \&) clearly show that significantly enhanced percentages of $\mathrm{N}, \mathrm{P}, \mathrm{K}$ and $\mathrm{Mg}$ in Anna apple trees' leaves in response to spraying the trees once, twice, thrice or four times with Moringa oil at 0.025 to $0.2 \%$. There was a gradual and significant promotion on these nutrients with increasing all concentrations and frequencies except concentrations among 0.1 and $0.2 \%$ and thrice and four times frequencies. Treating the trees four times with Moringa oil at $0.2 \%$ gave the maximum values Untreated the trees produced the minimum values. Similar results were announced during both seasons. 


\section{Yield/ tree:}

Carrying out one, two, three, or four sprays of Moringa oil at 0.025 to $0.2 \%$ significantly was responsible for improving Anna apple trees' yield rather than the control treatment. There was a gradual and significant promotion on the yield with increasing all concentrations (except among 0.1 and $0.2 \%$ ) and frequencies except three or four times. Therefore, from the economic point of view using Moringa oil at $0.1 \%$ three times is suggested to be the best treatment in this respect. Under such promised treatment yield/ tree reached 25.0 and $27.9 \mathrm{~kg}$ compared with the yield of untreated trees that reached 16.5 and $17.0 \mathrm{~kg}$ during both seasons. The percentage of increase on the yield due to the previous promised treatment's application reached 51.1 and $64.1 \%$ over the check treatment during both seasons, respectively. These results were true during both seasons.

\section{Fruit quality:}

It is worth mentioning that foliar applicationn of Moringa oil at 0.025 to $0.2 \%$, once, twice, thrice or four times significantly improved fruit quality of Anna apple trees in terms of increasing fruit weight, T.S.S., total and reducing sugars and total anthocyanins in the fruit peel and decreasing total acidity rather than nonapplication. The promotion of fruit quality was significantly associated with increasing concentrations and frequencies of Moringa oil in most cases. Increasing concentrations of Moringa oil from 0.1 to $0.2 \%$ and frequencies from thrice to four times failed significantly to show measurable effects on fruit quality. Therefore, the best results were obtained due to treating the trees three times with Moringa oil at $0.1 \%$. Unfavorable effects on fruit quality were attributed to the neglect of using Moringa oil. These results were true during both seasons.

Table 2. Effect of different concentrations and frequencies of Moringa oil on the leaf area and percentages of $\mathbf{N}$ and $P$ in the leaves of Anna apples during 2018 and 2019 seasons

\begin{tabular}{lccccccc}
\hline \multicolumn{1}{c}{ Moringa oil treatments } & \multicolumn{2}{c}{ Leaf area $(\mathbf{c m})^{\mathbf{2}}$} & \multicolumn{2}{c}{ Leaf N \% } & \multicolumn{2}{c}{ Leaf P \% } \\
\cline { 2 - 7 } & $\mathbf{2 0 1 8}$ & $\mathbf{2 0 1 9}$ & $\mathbf{2 0 1 8}$ & $\mathbf{2 0 1 9}$ & $\mathbf{2 0 1 8}$ & $\mathbf{2 0 1 9}$ \\
\hline Control & 9.1 & 8.8 & 1.61 & 1.62 & 0.17 & $\mathbf{0 . 1 7}$ \\
Moringa oil at $\mathbf{0 . 0 2 5} \%$ once & 10.2 & 9.9 & 1.69 & 1.70 & 0.19 & $\mathbf{0 . 2 0}$ \\
Moringa oil at $\mathbf{0 . 0 2 5} \%$ twice & 11.4 & 11.1 & 1.75 & 1.76 & 0.21 & $\mathbf{0 . 2 2}$ \\
Moringa oil at $\mathbf{0 . 0 2 5} \%$ thrice & 12.5 & 12.2 & 1.80 & 1.77 & 0.23 & $\mathbf{0 . 2 4}$ \\
Moringa oil at $\mathbf{0 . 0 2 5} \%$ four times & 12.6 & 12.3 & 1.81 & 1.78 & 0.23 & $\mathbf{0 . 2 5}$ \\
Moringa oil at $\mathbf{0 . 0 5} \%$ once & 11.4 & 11.1 & 1.81 & 1.82 & 0.21 & $\mathbf{0 . 2 2}$ \\
Moringa oil at $\mathbf{0 . 0 5} \%$ twice & 12.5 & 12.2 & 1.88 & 1.89 & 0.23 & $\mathbf{0 . 2 5}$ \\
Moringa oil at $\mathbf{0 . 0 5} \%$ thrice & 13.6 & 13.3 & 1.95 & 1.96 & 0.25 & $\mathbf{0 . 2 7}$ \\
Moringa oil at $\mathbf{0 . 0 5} \%$ four times & 13.7 & 13.4 & 1.96 & 1.97 & 0.25 & $\mathbf{0 . 2 8}$ \\
Moringa oil at $\mathbf{0 . 1} \%$ once & 13.7 & 13.4 & 1.95 & 1.96 & 0.23 & $\mathbf{0 . 2 6}$ \\
Moringa oil at $\mathbf{0 . 1} \%$ twice & 14.8 & 14.5 & 2.02 & 2.03 & 0.25 & $\mathbf{0 . 2 8}$ \\
Moringa oil at $\mathbf{0 . 1} \%$ thrice & 15.9 & 15.6 & 2.09 & 2.10 & 0.27 & $\mathbf{0 . 3 0}$ \\
Moringa oil at $\mathbf{0 . 1} \%$ four times & 16.0 & 15.7 & 2.10 & 2.11 & 0.28 & $\mathbf{0 . 3 1}$ \\
Moringa oil at $\mathbf{0 . 2} \%$ once & 13.8 & 13.5 & 1.95 & 1.96 & 0.23 & $\mathbf{0 . 2 6}$ \\
Moringa oil at $\mathbf{0 . 2} \%$ twice & 14.9 & 14.1 & 2.03 & 2.03 & 0.25 & $\mathbf{0 . 2 8}$ \\
Moringa oil at $\mathbf{0 . 2} \%$ thrice & 16.0 & 15.7 & 2.10 & 2.10 & 0.27 & $\mathbf{0 . 3 0}$ \\
Moringa oil at $\mathbf{0 . 2} \%$ four times & 16.1 & 15.8 & 2.11 & 2.11 & 0.28 & $\mathbf{0 . 3 1}$ \\
\hline New L.S.D. at 5\% & $\mathbf{1 . 0}$ & $\mathbf{1 . 0}$ & $\mathbf{0 . 0 6}$ & $\mathbf{0 . 0 5}$ & $\mathbf{0 . 0 2}$ & $\mathbf{0 . 0 2}$ \\
\hline
\end{tabular}


Table 3. Effect of different concentrations and frequencies of Moringa oil on the percentages of $\mathrm{K}$ and $\mathrm{Mg}$ in the leaves and yield/tree (kg.) of Anna apples during 2018 and 2019 seasons

\begin{tabular}{|c|c|c|c|c|c|c|}
\hline \multirow[t]{2}{*}{ Moringa oil treatments } & \multicolumn{2}{|c|}{ Leaf K \% } & \multicolumn{2}{|c|}{ Leaf Mg \% } & \multicolumn{2}{|c|}{ Yield / tree (kg.) } \\
\hline & 2018 & 2019 & 2018 & 2019 & 2018 & 2019 \\
\hline Control & 1.37 & 1.37 & 0.50 & 0.49 & 16.5 & 17.0 \\
\hline Moringa oil at $0.025 \%$ once & 1.42 & 1.43 & 0.54 & 0.53 & 17.1 & 18.9 \\
\hline Moringa oil at $0.025 \%$ twice & 1.47 & 1.48 & 0.57 & 0.57 & 17.7 & 20.0 \\
\hline Moringa oil at $0.025 \%$ thrice & 1.52 & 1.53 & 0.60 & 0.61 & 18.6 & 21.0 \\
\hline Moringa oil at $0.025 \%$ four times & 1.53 & 1.54 & 0.61 & 0.62 & 18.7 & 21.2 \\
\hline Moringa oil at $0.05 \%$ once & 1.50 & 1.49 & 0.58 & 0.62 & 17.9 & 20.5 \\
\hline Moringa oil at $0.05 \%$ twice & 1.55 & 1.55 & 0.62 & 0.66 & 18.8 & 21.5 \\
\hline Moringa oil at $0.05 \%$ thrice & 1.59 & 1.60 & 0.66 & 0.71 & 19.6 & 22.5 \\
\hline Moringa oil at $0.05 \%$ four times & 1.59 & 1.61 & 0.67 & 0.72 & 19.7 & 22.7 \\
\hline Moringa oil at $0.1 \%$ once & 1.55 & 1.55 & 0.66 & 0.71 & 19.0 & 22.9 \\
\hline Moringa oil at $0.1 \%$ twice & 1.61 & 1.60 & 0.71 & 0.76 & 22.9 & 25.9 \\
\hline Moringa oil at $0.1 \%$ thrice & 1.66 & 1.66 & 0.74 & 0.81 & 25.0 & 27.9 \\
\hline Moringa oil at $0.1 \%$ four times & 1.67 & 1.67 & 0.75 & 0.82 & 25.3 & 28.0 \\
\hline Moringa oil at $0.2 \%$ once & 1.55 & 1.55 & 0.66 & 0.71 & 19.0 & 23.0 \\
\hline Moringa oil at $0.2 \%$ twice & 1.62 & 1.60 & 0.71 & 0.76 & 23.0 & 26.0 \\
\hline Moringa oil at $0.2 \%$ thrice & 1.66 & 1.67 & 0.75 & 0.81 & 25.5 & 28.0 \\
\hline Moringa oil at $0.2 \%$ four times & 1.67 & 1.68 & 0.76 & 0.82 & 25.5 & 28.2 \\
\hline New L.S.D. at $5 \%$ & 0.04 & 0.04 & $\mathbf{0 . 0 3}$ & $\mathbf{0 . 0 3}$ & 0.5 & 0.6 \\
\hline
\end{tabular}

Table 4. Effect of different concentrations and frequencies of Moringa oil on some physical and chemical characteristics of the fruits of Anna apples during 2018 and 2019 seasons

\begin{tabular}{|c|c|c|c|c|c|c|}
\hline \multirow[t]{2}{*}{ Moringa oil treatments } & \multicolumn{2}{|c|}{ Fruit weight (g.) } & \multicolumn{2}{|c|}{ T.S.S. \% } & \multicolumn{2}{|c|}{ Total acidity \% } \\
\hline & 2018 & 2019 & 2018 & 2019 & 2018 & 2019 \\
\hline Control & 151.0 & 151.9 & 13.9 & 14.0 & 0.609 & 0.611 \\
\hline Moringa oil at $0.025 \%$ once & 158.0 & 160.0 & 14.1 & 14.1 & 0.580 & 0.574 \\
\hline Moringa oil at $0.025 \%$ twice & 164.0 & 167.0 & 14.4 & 14.4 & 0.550 & 0.540 \\
\hline Moringa oil at $0.025 \%$ thrice & 171.9 & 175.0 & 14.6 & 14.6 & 0.518 & 0.499 \\
\hline Moringa oil at $0.025 \%$ four times & 172.0 & 175.3 & 14.7 & 14.8 & 0.516 & 0.498 \\
\hline Moringa oil at $0.05 \%$ once & 166.0 & 176.0 & 14.4 & 14.5 & 0.518 & 0.540 \\
\hline Moringa oil at $0.05 \%$ twice & 172.3 & 183.0 & 14.7 & 14.8 & 0.471 & 0.510 \\
\hline Moringa oil at $0.05 \%$ thrice & 180.0 & 190.0 & 14.8 & 14.9 & 0.430 & 0.470 \\
\hline Moringa oil at $0.05 \%$ four times & 180.3 & 190.9 & 14.9 & 15.0 & 0.426 & 0.467 \\
\hline Moringa oil at $0.1 \%$ once & 174.0 & 184.0 & 14.7 & 14.7 & 0.470 & 0.510 \\
\hline Moringa oil at $0.1 \%$ twice & 181.0 & 190.0 & 15.0 & 15.0 & 0.431 & 0.460 \\
\hline Moringa oil at $0.1 \%$ thrice & 189.0 & 196.9 & 15.2 & 15.2 & 0.400 & 0.419 \\
\hline Moringa oil at $0.1 \%$ four times & 189.5 & 197.0 & 15.2 & 15.2 & 0.399 & 0.415 \\
\hline Moringa oil at $0.2 \%$ once & 174.0 & 184.0 & 14.7 & 14.7 & 0.464 & 0.505 \\
\hline Moringa oil at $0.2 \%$ twice & 181.0 & 190.5 & 15.0 & 15.0 & 0.430 & 0.459 \\
\hline Moringa oil at $0.2 \%$ thrice & 189.0 & 197.0 & 15.2 & 15.2 & 0.399 & 0.411 \\
\hline Moringa oil at $0.2 \%$ four times & 190.0 & 198.0 & 15.2 & 15.2 & 0.397 & 0.409 \\
\hline New L.S.D. at $5 \%$ & 5.5 & 5.9 & 0.2 & 0.2 & 0.028 & 0.027 \\
\hline
\end{tabular}


Table 5. Effect of different concentrations and frequencies of Moringa oil on some chemical characteristics of the fruits of Anna apples during 2018 and 2019 seasons

\begin{tabular}{|c|c|c|c|c|c|c|}
\hline \multirow[t]{2}{*}{ Moringa oil treatments } & \multicolumn{2}{|c|}{ Total sugars \% } & \multicolumn{2}{|c|}{ Reducing sugars \% } & \multicolumn{2}{|c|}{$\begin{array}{l}\text { Total anthocyanins } \\
(\mathrm{mg} / 100 \mathrm{~g} \mathrm{~F} . \mathrm{W} .)\end{array}$} \\
\hline & 2018 & 2019 & 2018 & 2019 & 2018 & 2019 \\
\hline Control & 6.7 & 6.5 & 3.5 & 3.4 & 6.2 & 6.3 \\
\hline Moringa oil at $0.025 \%$ once & 6.9 & 6.9 & 4 & 4.1 & 6.6 & 6.6 \\
\hline Moringa oil at $0.025 \%$ twice & 7.2 & 7.3 & 4.2 & 4.3 & 7.0 & 7.0 \\
\hline Moringa oil at $0.025 \%$ thrice & 7.5 & 7.6 & 4.5 & 4.6 & 7.5 & 7.6 \\
\hline Moringa oil at $0.025 \%$ four times & 7.6 & 7.7 & 4.5 & 4.6 & 7.6 & 7.7 \\
\hline Moringa oil at $0.05 \%$ once & 7.6 & 7.5 & 4.3 & 4.6 & 7.6 & 7.7 \\
\hline Moringa oil at $0.05 \%$ twice & 7.9 & 8 & 4.5 & 4.9 & 8.1 & 8.1 \\
\hline Moringa oil at $0.05 \%$ thrice & 8.2 & 8.3 & 4.7 & 5.2 & 8.6 & 8.6 \\
\hline Moringa oil at $0.05 \%$ four times & 8.3 & 8.4 & 4.8 & 5.2 & 8.7 & 8.7 \\
\hline Moringa oil at $0.1 \%$ once & 8.2 & 8.5 & 4.7 & 5.2 & 8.7 & 8.8 \\
\hline Moringa oil at $0.1 \%$ twice & 8.7 & 8.9 & 5 & 5.6 & 9.2 & 9.2 \\
\hline Moringa oil at $0.1 \%$ thrice & 9 & 9.3 & 5.3 & 5.7 & 9.9 & 9.6 \\
\hline Moringa oil at $0.1 \%$ four times & 9.1 & 9.4 & 5.4 & 5.3 & 9.9 & 9.6 \\
\hline Moringa oil at $0.2 \%$ once & 8.2 & 8.5 & 4.8 & 5.5 & 8.8 & 8.9 \\
\hline Moringa oil at $0.2 \%$ twice & 8.7 & 8.9 & 5 & 3.7 & 9.3 & 9.3 \\
\hline Moringa oil at $0.2 \%$ thrice & 9 & 9.4 & 5.4 & 5.8 & 10.0 & 9.7 \\
\hline Moringa oil at $0.2 \%$ four times & 9.1 & 9.5 & 5.5 & 4.9 & 10.0 & 9.7 \\
\hline New L.S.D. at 5\% & 0.2 & 0.2 & 0.2 & 0.2 & 0.3 & 0.3 \\
\hline
\end{tabular}

\section{DISCUSSION}

The higher content of Moringa oil from vitamins, nutrients, amino acids, proteins, plant pigments and fats (Srimal, 1997; Pons, 2003 and Parakash and Majeed, 2003) effectively emphasized the present results concerning the positive action of this oil on the fruiting of Anna apple trees.

These results are in agreement with those obtained by Borek, (2001); Amagase, (2006); Chowdhury et al., (2007); Amault and Auger, (2006); El- Masry and Abd El- Rahman, (2012); Mohamed and Mohamed, (2013); Gad El- Kareem and Abd El- Rahman, (2013); and Uwakiem, (2014); Sheren and El-Amary (2015); Nasira et al., (2016); Thanaa et al., (2017) and Fatma et al., (2020).

\section{CONCLUSION}

Carrying out three sprays at growth start and three weeks intervals of Moringa oil at $0.1 \%$ gave the best results concerning yield and fruit quality of Anna apple trees.

\section{REFERENCE}

Ahmed, F. F and M. H. Morsy. 1999. A new method for measuring leaf area in different fruit species. Minia. J. of Agric. Rec. \& Dev.19: 97 - 105.
Amagase, H. 2006. Clarifying the real bioactive constituents of garlic J. of Nutrition, 136: 7165-7255.

Amault, J and J. Auger. 2006. Seleno compounds in garlic and onion. J. of Chromatograhy A. 1112: 2336.

Association of Official Agricultural Chemists (A.O.A.C.). 2000. Official Methods of Analysis (A.O.A.C), $12^{\text {th }}$ Ed., Benjamin Franklin Station, Washington D.C., U.S.A. pp. 490-510.

Borek, C. 2001. Antioxidant healthy effects of aged garlic extract. J. of Nutrition. 131: $10105-10155$.

Chowdhury, M.N.A., M.A. Rahim, K.M. Khalequzzama, M.R. Humauan and M.M. Alan. 2007. Effect of plant extracts and time of application on incidence of anthracnose, yield and quality of mango. Inter. J. Sustain. Crop. Prod. 2 (5): 59-65.

El- masry, S.M.A and M.M.A. El- Rahman. 2012. Response of Taimour mango trees to foliar application of turmeric extract. Minia J. of Agric. Res. \& Develop. 32 (3): 37-49.

Fatma K. M. S., A. M. E. Gehan and Sh. M. M. Thanaa. 2020. Effects of salicylic acid, putrescine and moringa leaf extract application on storability, quality attributes and bioactive compounds of plum cv. 'Golden Japan'. Future of Food: Journal on Food, Agriculture and Society8 (2): 114.

Fulcki, T and F.J. Francis. 1968. Quantitative methods for anthocyanins 1- Extraction and determination for total anthocyanin. J. Food Sci. 33: 72-77. 
Gad El- Kareem, M.R and M.M. A. Abd El- Rahman. 2013. Response of Ruby seedless grapevines to foliar application of seaweed extract, salicylic acid and roselle extract. Hort. Sci. J. of Suez Canal Univ. 1: 299-303.

Mead, R., R.N. Currow and A.M. Harted. 1993. Statistical Methods in Agricultural and Experimental Biology. Second Ed. Chapman \& Hall. London, pp. 10- 44.

Mohamed, A.Y and H.H. Mohamed. 2013. The synergistic effects of using turmeric with various nutrients on fruiting of Sewy date palms. Hort. Sci. J. of Suez Canal Univ. 1: 287-291.

Nasira M., A. S. Khan, S. M.A. Basra and A. U. Malik. 2016. Foliar application of moringa leaf extract, potassium and zinc influence yield and fruit quality of 'Kinnow' mandarin. Scientia Hortic. 210: 227-235.

Parakash, L and S. Majeed. 2003. Multifunctional in gradients. The Nova Face of Natural C \& T. 118 (11): 41-47.

Pons, L.T. 2003. Fotoproteccion vegta II. Offar M, 22: 163164.
Sheren A. A and E.I. El-Amary. 2015. Improving growth and productivity of "Pear" trees using some natural plants extracts under north Sinai conditions. J Agric Veter Sci 8: 1-9.

Srimal, R.C. 1997. Turmeric a brief review of medicinal properties. Fitoterapia. 68(6): 483-494.

Thanaa, S.H.M., N.E. Kassim, M.S. AbouRayya and A.M. Abdalla. 2017. Influence of foliar application with mo-ringa (Moringa oleifera L.) leaf extract on yield and fruit quality of Hollywood plum cultivar. J Hortic 4, 193:1-7.

Uwakiem, M. Kh. A. 2014. The synergistic effect of spraying some plant extracts with some macro and micronutrients of Thompson seedless grapevines. Inter. J. of Plant and Soil Sci. 3 (10): 1290-1301.

Wilde, S. A., R. B. Corey, J. G. Layer and G. K. Voigt. 1985. Soils and Plant Analysis for Tree Culture. Oxford and IBH publishing Co., New Delhi, India. pp. 10-120.

\section{الملخص العربي \\ استجابة أثجار التفاح آنا للرش الورقى بزيت المورينجا \\ محمود رياض جاد الكريم}

الثمار مقارنة بمعاملة الكنترول. ارتبطت الزياذة معنويا بزيادة

تركيز وعدد مرات رش زيت المورينجا. زيادة التركيزات من

ا, • إلى ז, • ٪ وعدد مرات الرش من ثناث إلى أربع مرات

كان لها زيادة طفيفة.

تم الحصول على أفضل النتائج فيما يتعلق بالإنتاجية

وجودة الثمار لأشجار التفاح آنا عند معاملة الأشجار بالرش بالري

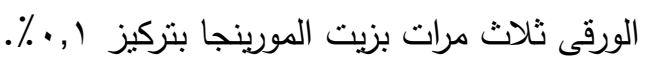

كلمات مفتاحية: تفاح آنا وزيت المورينجا
تم معاملة أشجار التفاح آنا بزيت المورينجا بنركيز

هr •, • إلى r, • ٪ مرة أو مرتين أو ثنلاث أو أربع مرات

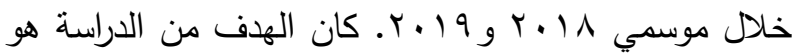

دراسة تأثنر نركيزات وعدد مرات الرش المختلفة من زيت المورينجا على النمو واثمار اشجار التفاح انا.

أوضحت النتائج ان المعاملة الورقية بزيت المورينجا

بتركيزات مختلفة وعدد مرات رش مختلفة كان له دور فى له

تعزيز النمو والحالة الغذائية للأشجار والمحصول وجودة 